\title{
The glyphosate controversy: an update
}

\section{A controvérsia do glifosato: uma atualização}

\author{
Sinji Borges Ferreira Tauhata' (1) (https://orcid.org/0000-0002-6617-4244) \\ Gabriela Bandeira de Araújo² (1) (https://orcid.org/0000-0003-3526-3823) \\ Suellen Daniela Ferraz de Oliveira Alves ${ }^{2}$ (1) (https://orcid.org/0000-0001-7203-6879) \\ Daniel Neves Vieira Martins ${ }^{3}$ (1) (https://orcid.org/0000-0002-8339-0109) \\ Luana Silva Lopes ${ }^{3}$ (1) (https://orcid.org/0000-0002-9921-6770) \\ Luciana Casaletti ${ }^{2,3, *}$ (1) (https://orcid.org/0000-0002-1790-0633)
}

\begin{abstract}
The demand for food in the world grows year after year due in part to population growth, but also to the improvement of emerging markets. Brazil is one of the largest food producers in the world. In 2017, its cereal, legume and oilseed crops totaled 238.6 million tons, $29.2 \%$ more than the year before. Much of the great increase in productivity is due to the incorporation of transgenic seeds, especially cotton, maize and soybean, which possess genes that will increase plant's adaptability to harsh soil and water conditions and, resistance to pests, but also tolerance to herbicides. Virtually, all transgenic soybeans planted in Brazil are resistant to glyphosate, the herbicide initially launched on the market by Monsanto in the 1970s under the trade name Roundup. Due to the existence of several transgenic crops tolerant to glyphosate, such as soy, wheat, corn and canola, this product is the most commercialized herbicide in the world. The use of glyphosate allows the sowing of transgenic crops immediately after application, making the planting and maintenance processes very practical. Soybeans, such as other transgenics, have biological safety already well defined, but the use of glyphosate is still an extremely controversial subject. This review presents some historical aspects of the binomial Roundup Ready soybean/ glyphosate and discusses the most recent controversies about the use of glyphosate in Brazil and worldwide.
\end{abstract}

KEYWORDS: herbicides; transgenic soy; toxicity; biosafety.
RESUMO: A demanda por alimentos no mundo cresce ano após ano devido em parte pelo aumento populacional, mas também pela melhoria dos mercados emergentes. O Brasil é um dos maiores produtores de alimentos do mundo. Em 2017, a safra nacional de cereais, leguminosas e oleaginosas totalizou 238,6 milhóes de toneladas, 29,2\% superior à obtida em 2016. Boa parte do grande aumento da produtividade se dá pela incorporaçáo de sementes transgênicas, especialmente de algodão, milho e soja, que apresentam genes que conferem maior adaptabilidade da planta ao solo, pragas, condições hídricas, mas também conferem resistência a herbicidas. Praticamente toda a soja transgênica plantada no país é resistente ao glifosato, inicialmente lançado no mercado pela empresa Monsanto nos anos 1970 pelo nome comercial Roundup, que é hoje o herbicida mais utilizado no mundo, principalmente pela disseminação da soja e outros produtos transgênicos como trigo, milho e canola. A utilização do glifosato permite a semeadura de culturas transgênicas imediatamente após a aplicação, tornando o processo de plantio muito prático. A soja, como outros transgênicos, apresenta segurança biológica já definida, mas a utilização do glifosato ainda é um assunto extremamente controverso. Esta revisão apresenta alguns aspectos históricos do binômio soja transgênica Roundup Ready/glifosato e discute as controvérsias mais recentes sobre o uso do glifosato no Brasil e no mundo.

PALAVRAS-CHAVE: herbicidas; soja transgênica; toxicidade; biossegurança. 
The modern world faces constant pressure to increase food production to support the ever-growing world population. New agricultural and biotechnological techniques are important in this regard and contribute to an increase in production. But at the same time, more progressive sectors of society, especially in Europe, also exert pressure for food production in a sustainable way, valuing family producers through organic production methods. The challenge, therefore, is to know what direction society should take for its general good. Thus, this dichotomy must be faced and studied in a rational and impartial way. This review presents some historical aspects of the Roundup Ready transgenic soybean / glyphosate binomial and discusses the most recent controversies about the use of glyphosate in Brazil and worldwide.

It is impregnated in the collective consciousness that transgenic foods are bizarre, cause several health problems and are mainly closely associated with large multinational companies in the biotechnology area, such as Basf, DuPont, Syngenta, Dow Agrosciences and the widely criticized Monsanto, recently acquired by Bayer. Among these companies, Monsanto is perhaps the most controversial, considering some of its cultivars were designed to be resistant to the pesticide that the company itself developed, especially the Roundup Ready transgenic soybean. One of Bayer's first actions was to discontinue the Monsanto brand to alleviate some of Monsanto's moral liabilities, inherited by Bayer (REBIÈRE; MAVOORI, 2020).

Transgenic foods are, in essence, a natural evolution in the classic genetic manipulation of plants and animals through the selection of crosses, in which the most desired characteristics are chosen for appearance, nutritional value, sensory properties and, more recently, aggregated commercial value. With the discovery of the structure of DNA, the mechanisms of genetic transmission and, mainly, the mechanisms of gene regulation, it was possible to use this knowledge to accelerate the process of genetic modification, no longer classic, but through the deletion and insertion of genes in microorganisms, plants and animals generating transgenics or genetically modified organisms (GMOs). In general, the world society sees the GMOs in a negative way, alleging something unnatural, or just creations from big companies aiming high profit. But the truth is that both multinational companies and universities or research institutes, often with government resources, invest in the development of new transgenic plants. Controversies aside, this must be done due to the benefits of such cultivars can provide for humanity (LEITE; MUNHOZ, 2013).

Transgenics plants can modify agriculture in several ways. A study on the cultivation of soybeans in the state of Mato Grosso do Sul, Brazil, concluded that the use of transgenic soybeans provides a lower production cost, reaching a savings of $14.8 \%$ considering all production variables (MENEGATTI; BARROS, 2007). Plants can be developed to adapt better to dry climates and saline soils (WANG et al., 2003). Transgenic cultivars can be produced to increase the nutritional value of the food, as for example in the work developed by FALCO et al. (1995), which increased the nutritional value of lysine in soy and canola. Genes can also be introduced in cultivars aiming at the expression of proteins with an insecticidal effect, as in the elegant work of NISHIZAWA et al. (2007), who created transgenic bean cultivars that are resistant to weevil attack. But perhaps the most widespread reason worldwide that leads to the abhorrence of transgenics is the insertion of genes that make the plant resistant to commercially used herbicides, such as glyphosate. Therefore, transgenic soy (Roundup Ready), resistant to the herbicide glyphosate, both developed and primarily commercialized by Monsanto, became a case study (PADGETTE et al., 1995).

Glyphosate [N-(phosphonomethyl) glycine] (Fig. 1) is the most nonselective herbicide used in modern agriculture. In lakes, it can be used in the elimination of aquatic plants and in the soil from preplanting to the productive phase, proving to be much more effective over other weed control methods (DILL et al., 2010).

Glyphosate was first synthesized in 1950 by the Swiss chemist Henri Martin at the former pharmaceutical company Cilag; however, no pharmaceutical applications were proposed at the time. It was only introduced as an herbicide in the 1970s by Monsanto under the trade name Roundup (DILL et al., 2010).

Glyphosate is a blocker of the enzyme 5-enolpyruvylshikimate-3-phosphate synthase (EPSPS) that catalyzes the reaction of shikimate-3-phosphate to 5-enolpyruvylshikimate3-phosphate (EPSP). This reaction belongs to the cycle of shikimic acid and is present in all plants, bacteria, and fungi, but absent in animals. The cycle of shikimic acid is important for the biosynthesis of aromatic amino acids: phenylalanine, tryptophan, and tyrosine and for this reason it is an excellent target for the development of microbicides and herbicides. Plants under the action of glyphosate cannot synthesize essential proteins, do not synthesize lignin, alkaloids, flavonoids and, therefore, cannot flourish (DILL et al., 2010). Because of its extreme phytotoxicity, it is also lethal for plants of commercial interest, so during its handling it must be applied with caution between the lines of different commercial cultures, such as coffee, citrus, apple, etc. However, it was with the advent of transgenic crops, resistant to glyphosate, which its use on a large scale has expanded exponentially. The cultivation of transgenic soy together with glyphosate represents an important binomial for the world agroeconomics (DILL et al., 2010).

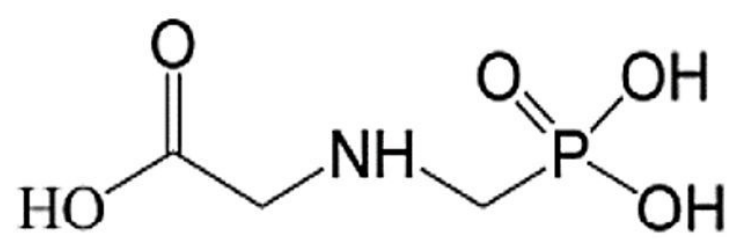

Figure 1. The chemical structure of glyphosate. 
Soy $($ Glycine $\max \mathrm{L}$ ) is a plant originally from China, part of the Fabaceae family (legumes), as well as peas, beans, and lentils. It is fully domesticated and is now considered a commodity due to its great economic importance. As an oilseed, soy is the raw material for the extraction of vegetable oil used globally for human consumption and biofuel. It is also an excellent source of protein for human consumption, especially through fermented products, and animal feed with the use of the processing by-products, such as husk and bran (QIU; CHANG, 2010).

Brazil, the United States, Argentina, and China are the world's largest soy producers. For these countries, the production of 126.0, 96.8, 54.0 and 18.1 million tons of the product was projected for the 2019/2020 harvest, respectively (FIESP, 2020). In Brazil, these data represented an increase of $100 \%$ in 10 years and about $500 \%$ in 20 years (BALBINOT JUNIOR et al., 2017). Until 1950s, soy was only a modest crop for domestic production of animal fodder, and rapidly became the main product of Brazilian agribusiness, especially due to the demand of world markets, mainly China. The great world demand caused the producers to expand the planted area, but they also sought an increase in production per hectare planted. Such demands were achieved with the development of several product variations. According to the Brazilian Ministry of Agriculture, Livestock and Supply (MAPA), there are more than 3000 soybean cultivars registered with the National Cultivar Production Service, which meets the needs of each Brazilian producing region (BRAZIL, 2020). Due to higher productivity and profitability, in 2016/2017, $96.5 \%$ of the soybean crop were GMO crops.

Shortly after launching on the market, the phytotoxic action of the herbicide glyphosate seemed solid, but several findings have led to the discovery of some resistant plants and microorganisms, on all continents (POWLES, 2008). One of the best defense mechanisms against glyphosate was discovered in Agrobacterium spp., gram-negative bacteria that induce the formation of hyperplastic tissue at the junction between the stem and the root (crown gall) in vines and other fruit plants of commercial interest (ANDRADE et al., 2003). The Agrobacterium sp. strain CP4 has a variant of EPSP synthase class II that retains enzymatic activity even complexed with glyphosate, which gives to Agrobacterium sp. resistance to the herbicide, which led Monsanto's biotechnological division to seize the gene from ESPS CP4 and introducing it in some soybean cultivars with the objective of making them tolerant to glyphosate, creating Roundup Ready soybeans (PADGETTE et al., 1995).

Since its launch until today, the use of Roundup Ready soy and its variants has grown exponentially, always with the concomitant use of glyphosate, significantly increasing its productivity per hectare, compared to non-GMO cultivars. In Brazil, the cultivation of transgenic soybeans has recently increased consistently over the harvests. For example, considering the 2016/2017 harvest, the planting of transgenic soybeans corresponded to 32.7 million hectares. Considering the 2018/2019 harvest, the planting of transgenic soybeans in Brazil corresponded to 34.86 million hectares, or $95.7 \%$ of the total cultivated area, surpassing for the first time the USA with 34.09 million hectares (SANTOS et al. 2019). Due to this fact, in parallel with the growing increase in Roundup Ready soy planting, the use of the glyphosate herbicide is also expanding.

In 2014, it was estimated that 113 million tons of glyphosate were applied to transgenic soybean crops in the USA alone (BENBROOK, 2016). There are no data for Brazil, but as soybean production on Brazilian soil is close to American production, the use of glyphosate in Brazil should also reach millions of tons. With the patent breaking in 2000, glyphosate today is not exclusively produced by Monsanto/Bayer. Various formulations from other companies have also been used (BENBROOK, 2016).

Glyphosate is a very stable chemical compound, suffering little chemical degradation in soil or water, only a few cases of photolysis. Microbial degradation is the principal way of eliminating glyphosate, especially in aqueous media (SOLOMON; THOMPSON, 2003; DILL et al., 2010). In an aquatic environment, the product complexes with the organic matter of rivers and lakes, which helps to eliminate the herbicide from the water, reducing the exposure of aquatic organisms. It is worth mentioning that glyphosate degradation products are also not bioaccumulative. Thus, it has been characterized as an herbicide with low toxicity for wildlife in aquatic environments, such as birds, mammals, fish, aquatic invertebrates, considering the standard use of glyphosate in crops, which is approximately $4 \mathrm{~kg}$ per hectare of planted area (SOLOMON; THOMPSON, 2003).

In the soil, glyphosate is degraded by aerobic and anaerobic microorganisms present in the microflora through two main metabolic pathways. The first results in the formation of sarcosine and inorganic phosphate and the second through a C-P lyase enzyme. The same break can be nonenzymatically performed in soils rich in manganese oxide or enzymatically through soil ligninolytic enzymes. The other way of glyphosate degradation is through glyphosate oxidoreductases (GOX), in which case the glyphosate is converted into aminomethylphosphonic acid (AMPA) and glyoxylate. The AMPA can also be a substrate of C-P lyase and later oxidized to $\mathrm{CO}_{2}$ and the second is used in the glyoxylate cycle present in plants and microorganisms (Fig. 2) (DUKE, 2011). It is estimated that in the soil 79 to $86 \%$ of glyphosate is converted to $\mathrm{CO}_{2}$ in approximately 6 months.

Biodegradation is also responsible for eliminating glyphosate in rivers and lakes, in a similar way: up to AMPA and later up to $\mathrm{CO}_{2}$ (DUKE, 2011). In plants, its pathway of metabolic degradation is not well understood, possibly not existent. It is known, however, that in a short time glyphosate is metabolized to AMPA, but it is believed that this conversion occurs thanks 


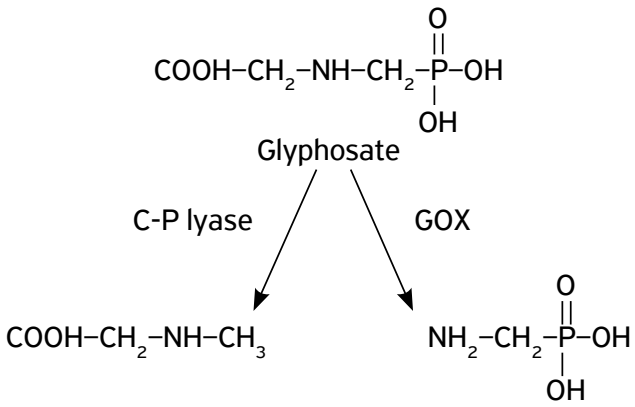

Sacosine

Figure 2. The two pathways of glyphosate degradation by microbial enzymes.

to endophytic microorganisms (DILL et al., 2010). Pseudomonas sp., Rhizobium sp. and Streptomyces sp. are examples of microorganisms that metabolize glyphosate through C-P lyase while Arthrobacter atrocyaneus and Pseudomonas sp. perform their metabolism through GOX. Before the discovery of ESPS $\mathrm{CP} 4$, one of the attempts to create genetically modified plants resistant to glyphosate was to incorporate the GOX gene of microorganisms in crops of commercial interest. For example, Ochrobactrum anthropi GOX gene (goxv247) has been isolated and successfully inserted into canola cultivars with relative commercial success (GREEN, 2009).

Despite the great toxicity to plants and some microorganisms, glyphosate is not very toxic to animals since they do not have the cycle of shikimic acid. Animals obtain aromatic amino acids exclusively through diet. Even so, several studies have been and are constantly being carried out on the toxicity of glyphosate and its metabolite AMPA in fish, plankton, mammals, mainly humans, as discussed below.

Studies on glyphosate on levels of cortisol, glucose, ions, enzymes, and other biological parameters of neotropical fish Prochilodus lineatus (Curimbatá) (LANGIANO; MARTINEZ, 2008) established that glyphosate toxicity is, in fact, much less when compared to other herbicides. Only changes in the level of cortisol, hepatic glucose catalase were detected, indicating a typical stress response. VENDRELL et al. (2009) also confirm that glyphosate is not a dangerous herbicide for lake phytoplankton due to its low toxicity to three species of algae, due to the low concentration of the compound in water. However, the authors do not rule out the possibility of acute toxicity at the sources of the contamination when the glyphosate concentration is high. However, in the studied ecosystem, no such event was identified.

In animals, glyphosate has low toxicity because it is poorly absorbed by the body (only 30 to $36 \%$ is, in fact, absorbed, feces being the main route of elimination). In high doses $(1 \mathrm{mg} / \mathrm{kg})$ only 19 to $23 \%$ is effectively absorbed. The main reason for this low absorption is the low pKa of phosphonic acid. This causes ionization of glyphosate in the physiological $\mathrm{pH}$ (intestinal

lumen), therefore little absorbed (WILLIAMS et al., 2000; ACQUAVELLA et al., 2001).

In general, the glyphosate applying formulation varies from 0.5 to $1 \mathrm{~L} / 100 \mathrm{~L}$ of water, making the concentration in the solution to be used from 0.18 to $0.36 \mathrm{mg} / \mathrm{L}$ (ROUNDUP ORIGINAL, 2018). It is established that the lethal dose (LD50) of the oral ingestion of pure glyphosate is $4.23 \mathrm{~g} / \mathrm{kg}$, while the manufacturer Monsanto/Bayer cites LD50 of $5.6 \mathrm{~g} / \mathrm{kg}$, which is extremely high in both cases. To reach this concentration, a $70 \mathrm{~kg}$ adult should drink about $820 \mathrm{~mL}$ of the concentrated solution or 800 to $1600 \mathrm{~L}$ of the diluted solution, which characterizes it as an herbicide of extremely low toxicity. However, it is known that accidental ingestions $>85 \mathrm{~mL}$ of a concentrated glyphosate formulation are associated with certain toxicity in adults, with the presence of corrosive effects on the mouth, throat, stomach, dysphagia, and epigastric pain. Effects on other organs are also reported, such as low liver and renal perfusion, pulmonary edema, ventricular arrhythmia, bradycardia, metabolic acidosis, conjunctivitis, nasal discomfort, dermatitis and, in rare cases, skin burns (BRADBERRY et al., 2004). Treatment is supportive for the elimination of symptoms and decontamination, but the person hardly dies.

A controversial review article published in 2013 by Samsel and Sennef establishes that glyphosate is the cause of several chronic diseases present in current western society, including obesity, gastrointestinal disorders such as celiac disease and gluten intolerance, diabetes, heart disease, depression, cancer, infertility, Alzheimer's and autism. The authors reached the conclusion based on two assumptions: The first is due to the fact that glyphosate is an inhibitor of cytochrome P450 (CYP) enzymes, which is responsible for the detoxification of numerous xenobiotic compounds (SAMSEL; SENNEF, 2013a). This would lead to nondestruction and accumulation of toxins in cells and the body, which would cause widespread systemic damage. The second assumption is based on the fact that glyphosate inhibits the growth of some species of bacteria in the intestinal flora, which would lead to the disruption of the perfect symbiosis between intestinal flora and their host, with regard to the production and exchange of nutrients, with emphasis on production of essential aromatic amino acids (SAMSEL; SENNEF, 2013a). Following this publication, the same authors published a series of other articles with more concrete data trying to corroborate the allegations (SAMSEL; SENNEF, 2013b; 2015). The authors proposed that the toxic effect of glyphosate would be due to several factors: the ability of glyphosate to chelate several important ions for the functioning of cytochrome P450 enzymes, the chelation and the consequent decrease in serum magnesium that would lead to neurological diseases, also the fact that it can replace the amino acid glycine, including in the composition of peptides and finally the strong association with aluminum, 
which would lead to greater contamination by this heavy metal (SENNEF et al., 2015).

Facing vast allegations of toxicity, glyphosate once again ended up on the dock in a way scientific community and regulatory bodies decided to analyze the literature again to corroborate or refute the research group's arguments. In 2015 in Europe, the European Food Safety Authority (EFSA) conducted a detailed study refuting Samsel and Sennef's data stating that glyphosate poses no risk to human health, revalidating the license to use the product in the European Union (EFSA, 2015). In 2017, the license was renewed for another 5 years. Also, in 2017, the European Chemicals Agency (ECHA) classified, based on the information available, that there is no evidence between glyphosate and cancer and that glyphosate should not be classified as a mutagen. The same conclusions were reached by EFSA and authorities in Japan, Canada, Australia and New Zealand and the United Nations through the joint statement from the World Health Organization (WHO) and the United Nations Food and Agriculture Organization (FAO) (JMPR, 2016). The research group's findings were also refuted by several researchers around the world, the most emphatic being the work of MESNAGE; ANTONIOU (2017), which refuted point to point the statements presented in SAMSEL; SENNEF (2013a), accusing the authors of inappropriately employing a deductive reasoning approach based on syllogism. MESNAGE; ANTONIOU (2017) stated that there is no scientific evidence available which corroborates the data presented and that they only serve to create a distraction and not lead to a rational direction on glyphosate toxicity.

But the controversy surrounding glyphosate gained a new chapter in mid-2018. In a historic multimillion-dollar lawsuit in the US state of California, Monsanto/Bayer was ordered to pay financial compensation to a groundskeeper with non-Hodgkin's lymphoma who claimed his illness was caused for the constant use of Roundup throughout his professional life. The jury agreed with the plaintiff who claimed Monsanto had failed to warn him and other consumers of the cancer risks posed by its weed killers. In a globalized world, the repercussion of the case was immediate, with the temporary ban in some countries, including Brazil by court order. The timing could not be worse, because of the beginning of soy planting in the country, which for the most part is transgenic. It is a legal-governmental imbroglio with the potential to severely compromise the country's soybean crop.

In Brazil, research, experimentation, production, packaging and labeling, transport, storage, marketing, commercial advertising, use, import, export, the final destination of waste and packaging, registration, the classification, control, inspection and inspection of pesticides complies with the Law No. 7802 of June 11, 1989 (BRAZIL, 1989). It is a piece of relatively strict legislation that prohibits the use of teratogenic, mutagenic, and carcinogenic substances, accordingly with the scientific community and with the National Health Surveillance
Agency (ANVISA) being the main regulator and enforcer of this law. The glyphosate herbicide meets the standards and, therefore, can be used in the country. However, also in mid-2018 the MAPA initiated a national discussion by proposing the vote on Bill No. 6299/2002 that modifies the law No. 7802/1989 making it less restrictive, which by the new interpretation would increase the number of agricultural products that can be used in the country (BRAZIL, 2002); in addition, it transfers decisions on the release of pesticides from ANVISA to the MAPA. With permits, relaxations, or prohibitions on the use of glyphosate and other herbicides, Brazil is the perfect example of legal uncertainty on the subject.

If glyphosate toxicological safety is still controversial, the same cannot be said of its different formulations. To increase the absorption of glyphosate by the leaves of plants, several manufacturers add products to optimize the systemic incorporation of the herbicide. The most used is polyoxyethyleneamine (POEA) (BRADBERRY et al., 2004).

To determine the toxicity of the POEA surfactant, ADAM et al. (1997) carried out toxicity tests on three groups of eight rats. The authors tested separately pure Roundup, isopropylamide glyphosate $41 \%$ (same concentration of glyphosate in Roundup) and POEA 18\% (approximately the concentration of POEA in Roundup). The authors found that $25 \%$ of animal mortality was present in the group where only POEA was used. The authors concluded that POEA causes much more gastrointestinal and other organ damage than glyphosate itself (ADAM et al., 1997). Similar work has been carried out by other research groups with similar results, making it a consensus today that the POEA surfactant is far more toxic than glyphosate itself (BRADBERRY et al., 2004). It is believed that most of the Roundup poisoning notifications are, in fact, by POEA and not by glyphosate. Thus, this fact does not disqualify the lawsuits (won or in progress) against Monsanto/Bayer for causing health problems, since the company does not properly label its main herbicide regarding health risks.

As a corporation, Monsanto/Bayer itself is concerned about possible lawsuits related to Roundup, so in a public statement the company said that a transition is being made in its products to eliminate the use of POEA. The path to eliminate POEA is under way, at least in Europe, since the major surfactants used in EU Monsanto's Roundup formulations is a propoxylated quaternary ammonium, also known as Dodigen 4022, which has been recently reported to be 10 to $100 \times$ less toxic when compared with former Roundup formulations containing POEA (Mesnagea et al., 2019). However, despite the toxicity of the POEA surfactant, exposure to it through the diet is minimal, since surfactants are not systematically transported in plants in the same way as glyphosate (SHERRICK et al., 1986). Thus, the greatest risks are related to the handling of formulations that contain this surfactant. 
The controversy over GMOs and the use of the herbicide glyphosate is far from over. There are clearly two well-defined positions on the subject, one with more progressive guidelines, mainly in Europe in favor to ban the use glyphosate and the production of transgenic foods. The other is a more conservative position, especially in the USA, Canada, Argentina, and Brazil, which wants to maintain or expand GMO crops and the widespread use of glyphosate and other herbicides. Contradictorily to these positions, glyphosate is still approved to be used in Europe for a few more years, while the USA saw a citizen's first case in a lawsuit against
Monsanto/Bayer involving glyphosate, which have the potential to cause some turmoil (NYT, 2018).

In Brazil, the change in the government are facilitating the use of glyphosate and other herbicides. In 2018, the Bill No. 6299/2002 was approved in a Special Committee of the Brazilian National Congress, the first step to become effective Law. In addition, MAPA published the Act No. 58/2019 where it reclassifies several pesticides (BRAZIL, 2019). In this, 93 products formulated with glyphosate had their classification of reduced toxicity of Class II (highly toxic) for Category 5 (improbable product to cause acute damage), showing the direction to be followed by regulatory bodies of the new Brazilian government.

\section{ACKNOWLEDGEMENTS: Not applicable.}

FUNDING: This work did not receive any specific grant from funding agencies in the public, commercial, or not-for-profit sectors.

CONFLICTS OF INTEREST: All authors declare that they have no conflict of interest.

ETHICAL APPROVAL: Not applicable.

AVAILABILITY OF DATA AND MATERIAL: Data sharing not applicable to this article as no datasets were generated or analyzed during the current study.

AUTHORS' CONTRIBUTIONS: Conceptualization: Casaletti, L.; Tauhata, S. B. F. Literature search: Tauhata, S. B. F.; Araújo, G. B.; Alves, S. D. F. O.; Martins, D. N. V.; Lopes, L. S. Formal analysis: Tauhata, S. B. F.; Araújo, G. B.; Alves, S. D. F. O.;

Martins, D. N. V.; Lopes, L. S. Writing - original draft: Tauhata, S. B. F.; Casaletti, L. Writing - review \& editing: Tauhata, S. B. F.; Casaletti, L.

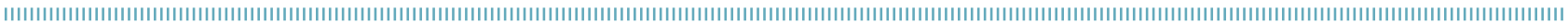

\section{REFERENCES}

ACQUAVELLA, J.F.; COWELL, J.E.; CULLEN, M.R.; FARMER, D.R.; PASTIDES, H. Implications of Glyphosate Toxicology and Human Biomonitoring Data for Epidemiologic Research. Journal of Agromedicine, Seattle, v.7, n.4, p.7-27, 2001. https://doi. org/10.1300/J096v07n04_02

ADAM, A.; MARZUKI, A.; RAHMAN, H.A.; AZIZ, M.A. The Oral and Intratracheal Toxicities of ROUNDUP and its Components to Rats. Veterinary and Human Toxicology, United States, v.39, n.3, p.147-51, 1997.

ANDRADE, G.M; SARTORETTO, L.M.; BRASILEIRO, A.C.M. Biologia molecular do processo de infecção por Agrobacterium spp. Fitopatologia Brasileira, v.28, n.5, p.465-476, 2003.

BALBINOT JUNIOR, A.A.; HIRAKURI, M.H.; FRANCHINI, J.C.; DEBIASI, H.; RIBEIRO, R.H. Análise da área, produção e produtividade da soja no Brasilem duas décadas (1997-2016). Londrina: Embrapa Soja, 2017. Available from: https://ainfo.cnptia.embrapa.br/digital/bitstream/ item/156652/1/Boletim-de-PD-1 1.pdf. Access on: 27 Aug. 2020.

BENBROOK, C.M. Trends in Glyphosate Herbicide use in the United States and Globally. Environmental Sciences Europe, Frankfurt, v.28, p.3, 2016. https://doi.org/10.1 186/s12302-016-0070-0
BRADBERRY, S.M;PROUDFOOT, A.T.; VALE, J.A. Glyphosate Poisoning. Toxicological Reviews, United Kingdom, v.23, n.3, p.159-167, 2004. https://doi.org/10.2165/00139709-200423030-00003

BRAZIL. Câmara dos Deputados. Projeto de Lei no. 6.299/2002, 2002. Brasília: Diário Oficial da União. 2002. Available from: https://www.camara.gov.br/proposicoesWeb/prop_mostrarinteg ra?codteor $=1654426 \&$ filename $=$ Tramitacao $-P L+6299 / 2002$. Access on: 27 Aug. 2020.

BRAZIL. Ministério da Agricultura, Pecuária e Abastecimento. Ato №. 58, de 27 de agosto de 2019. Brasília: Diário Oficial da União. 2019. Available from: https://www.in.gov.br/en/web/ dou/-/ato-n-58-de-27-de-agosto-de-2019-213474289. Access on: 27 Aug. 2020.

BRAZIL, Ministério da Agricultura, Pecuária e Abastecimento. CultivarWeb-Registro Nacional de Cultivares - RNC. 2020. Available from: http://sistemas.agricultura.gov.br/snpc/cultivarweb/ cultivares_registradas.php. Access on: 3 Nov. 2020.

BRAZIL. Presidência da República. Leino. 7802, de 11 de junho de 1989. Brasília: Diário Oficial da União. 1989. Available from: http://www. planalto.gov.br/ccivil_03/LEIS/L7802.htm. Access on: 27 Aug. 2020. 
DILL, G.M. et al. Glyphosate: Discovery, Development, Applications and Properties. In: NANDULA, V.K. (ed). Glyphosate Resistance in crops and weeds: history, development and management. Hoboken: John Wiley \& Sons, 2010. https://doi. org/10.1002/9780470634394.ch 1

DUKE, S.O. Glyphosate degradation in glyphosate-resistant and -susceptible crops and weeds. Journal of Agricultural and Food Chemistry, München, v.59, n.1 1, p.5835-5841, 2011 . https:// doi.org/10.1021/jf102704x

EUROPEAN FOOD SAFETY AUTHORITY (EFSA). Conclusion on the peer review of the pesticide risk assessment of the active substance glyphosate. EFSA Journal, Parma, v. 13, n. 11 , p.4302, 2015. Available from: https://efsa.onlinelibrary. wiley.com/doi/pdf/10.2903/j.efsa.2015.4302. Access on: 27 Aug. 2020.

FALCO, S.C.; GIDA, T.; LOCKE, M.; MAUVAIS, J.; SANDERS, C.; WARD, R.T.; WEBBER, P. Transgenic Canola and Soybean Seeds with Increased Lysine. Nature Biotechnology, New York, v.13, p.577-582, 1995. https://doi.org/10.1038/nbt0695-577

FEDERAÇÃO DAS INDÚSTRIAS DO ESTADO DE SÃO PAULO (FIESP). Safra Mundial de soja 2019/2020 - $11^{\circ}$ Levantamento do USDA. 2020. Available from: https://www.fiesp.com.br/ arquivo-download/?id=266064. Access on: 3 Nov. 2020.

GREEN, J.M. Evolution of Glyphosate-Resistant Crop Technology. Weed Science, Georgia, v.57, n. 1, p. 108-1 17, 2009. https://doi. org/10.1614/WS-08-030.1

JOINT FAO/WHO MEETING ON PESTICIDE RESIDUES (JMPR). Summary Report. Geneva: FAO/WHO, 2016. Available from: http://www.who.int/foodsafety/jmprsummary2016.pdf. Access on: 27 Aug. 2020.

LANGIANO, V.C.; MARTINEZ, C.B.R. Toxicity and Effects of a Glyphosate-Based Herbicide on the Neotropical Fish Prochilodus lineatus. Comparative Biochemistry and Physiology Part C: Toxicology () Pharmacology, Miami, v.147, n.2, p.222-231, 2008. https:// doi.org/10.1016/j.cbpc.2007.09.009

LEITE, D.S.; MUNHOZ, L.L. Biotecnologia e Melhoramento das Variedades de Vegetais: Cultivares e Transgênicos. Veredas do Direito, v10, n.19, p.23-44. 2013.

MENEGATTI, A.L.A.; BARROS, A.L.M. Análise comparativa dos custos de produção entre soja transgênica e convencional: um estudo de caso para o Estado do Mato Grosso do Sul. Revista de Economia e Sociologia Rural, Brasília, v.45, n.1, p.163-183, 2007. https://doi.org/10.1590/ S0103-20032007000100008

MESNAGE, R.; ANTONIOU, M.N. Facts and Fallacies in the Debate on Glyphosate Toxicity. Frontiers in Public Health, Lausanne, v.5, p.316, 2017. https://doi.org/10.3389/ fpubh.2017.00316965

MESNAGE, R.; BENBROOK, C.; ANTONIOU, M.N. Insight into the confusion over surfactant co-formulants in glyphosate-based herbicides. Food and Chemical Toxicology, Reus, v. 128, p.137-145, 2019. https://doi.org/10.1016/j.fct.2019.03.053
NISHIZAWA, K.; TERAISHI, M.; UTSUMI, S.; ISHIMOTO, M. Assessment of the importance of $\alpha$-amylase inhibitor- 2 in bruchid resistance of wild common bean. Theoretical and Applied Genetics, Stuttgart, v.114, n.4, p.755-764, 2007. https://doi. org/10.1007/s00122-006-0476-y

NYT (The New York Times). MONSANTO Ordered to Pay \$289 Million in Roundup Cancer Trial. The New York Times, New York, 10 August 2018. Available from: https://www.nytimes. com/2018/08/10/business/monsanto-roundup-cancer-trial. html. Access on: 3 Nov. 2020.

PADGETTE, S.R. et al. Development, Identification and Characterization of a Glyphosate-Tolerant Soybean Line. Crop Science, College Station, v.35, n.5, p.1451-1461, 1995. https:// doi.org/10.2135/cropsci $1995.0011183 \times 003500050032 x$

POWLES, S.B. Evolved glyphosate-resistant weeds around the world: lessons to be learnt. Pest Management Science, Oxford, v.64, n.4, p.360-365, 2008. https://doi.org/10.1002/ps.1525

QIU, L.-J.; CHANG, R.-Z. The Origin and History of Soybean. In SINGH, G. The Soybean: Botany, Production and Uses. Wallingford: CABI, 2010. p.1-23.

REBIĖRE, P.; MAVOORI, H. The Bayer-Monsanto fusion: countering brand tarnishing and rebuilding reputation. Journal of Business Strategy, United Kingdom, v.41, n.1, p.27-37, 2020. https:// doi.org/10.1108/JBS-10-2018-0185

ROUNDUP ORIGINAL. Roudup original, bula de utilização. São Paulo: Monsanto do Brasil, 2018. Available from: http://www.roundup. com.br/pdf/roundup_original/roundup-original-bula-monsanto. pdf. Access on: 4 Nov. 2020.

SAMSEL, A.; SENEFF, S. Glyphosate, pathways to modern diseases II: Celiac sprue and gluten intolerance. Interdisciplinary Toxicology, Bratislava, v.6, n.4, p.159-184, 2013b. https://doi.org/10.2478/ intox-2013-0026

SAMSEL, A.; SENEFF, S. Glyphosate, pathways to modern diseases III: Manganese, neurological diseases and associated pathologies. Surgical Neurology International, New York, v.6, p.45, 2015. https://doi.org/10.4103/2152-7806.153876

SAMSEL, A.; SENEFF, S. Glyphosate's Suppression of Cytochrome P450 Enzymes and Amino Acid Biosynthesis by the Gut Microbiome: Pathways to Modern Diseases. Entropy, Albany, v.15, n.4, p. 1416 1463, 2013a. https://doi.org/10.3390/e15041416

SANTOS, D. et al. (2019). Informativo de Biotecnologia Céleres". IB 19.01. Céleres. 2019. Available from: http://www.celeres. com.br/wp-content/uploads/2019/11/BoletimBiotecnologiaC \%C3\%A9leres_Novembro2019-2.pdf. Access on: 3 Nov. 2020.

SENEFF, S.; SWANSON, N.; LI, C. Aluminum and Glyphosate Can Synergistically Induce Pineal Gland Pathology: Connection to Gut Dysbiosis and Neurological Disease. Agricultural Sciences, Milan, v.6, n. 1, p.42-70, 2015. https://doi.org/10.4236/as.2015.61005

SHERRICK, S.L.; HOLT, H.A.; HESS, F.D. Absorption and Translocation of MON 0818 Adjuvant in Field Bindweed (Convolvulus arvensis). Weed Science, Georgia, v.34, n.6, p.817-823, 1986. https://doi. org/10.1017/SOO43174500067941 
SOLOMON, K.R.; THOMPSON, D.G. Ecological Risk Assessment for Aquatic Organisms from Over-Water Uses of Glyphosate. Journal of Toxicology and Environmental Health, Part B, Ottawa, v.6, n.3, p.289-324, 2003. https://doi.org/10.1080/10937400306468

VENDRELL, E.; FERRAZ, D.G.B.; SABATER, C.; CARRASCO, J.M. Effect of Glyphosate on Growth of Four Freshwater Species of Phytoplankton: A Microplate Bioassay. Bulletin of Environmental Contamination and Toxicology, Windsor, v.82, n.5, p.538-542, 2009. https://doi.org/10.1007/s00128-009-9674-z
WANG, W.; VINOCUR, B.; ALTMAN, A. Plant responses to drought, salinity and extreme temperatures: towards genetic engineering for stress tolerance. Planta, Bonn, v.218, n.1, p.1-14, 2003. https://doi.org/10.1007/s00425-003-1 105-5

WILLIAMS, G.M.; KROES, R.; MUNRO, I.C. Safety Evaluation and Risk Assessment of the Herbicide Roundup and Its Active Ingredient, Glyphosate, for Humans. Regulatory Toxicology and Pharmacology, Falls Church, v.31, n.2, p.117-164, 2000. https:// doi.org/10.1006/rtph.1999.1371 